\title{
Media Literacy Capabilities of Broadcast Monitoring in Regional Indonesian Broadcasting Commission (KPID) of West Java
}

\author{
DEDEH FARDIAH \\ FERRY DARMAWAN \\ RINI RINAWATI \\ Universitas Islam Bandung, Indonesia
}

\begin{abstract}
The role of media literacy is significantly needed to ward off the harmful effects of the media, especially television. Ideally, media literacy skills should be possessed by all people to avoid numerous harmful effects of television. The Indonesian broadcasting commission (KPI) as the broadcast regulator in Indonesia has the task of monitoring broadcast content and also educating the public to be media literate. In conducting its duties, it involves the community to monitor broadcasts by forming volunteers, known as broadcast monitors. This study uses a quantitative approach to examine accessibility, analysis, evaluation, and broadcast monitoring communication in supporting broadcast regulator performance. The research object is broadcast monitors supervised by the Regional Indonesian Broadcasting Commission (KPID) of West Java Province in 2018. The monitors consist of five batches from five regions in West Java, namely Sumedang, Subang, Karawang, Bogor, and Bandung. Based on the research results, it shows that the media literacy capability of broadcast monitors is high, both in terms of the ability to access the media, analyze television programs and evaluate them, and even communicate the results of their monitoring to KPID West Java. The high level of media literacy has decent implications for the high participation of broadcast monitors to make complaints and the frequent findings of violations related to broadcast contents.
\end{abstract}

Keywords: Media literacy, broadcasting, regulation, regulator, television.

\section{INTRODUCTION}

Indonesia is a country that has high accessibility to media exposure. Every day, Indonesian people consuming media in various forms, be it print media, electronic media, and even online media. However, ironically, this condition is not always in line with people's ability to digest media. There are still many people who do not have media literacy capabilities, even though understanding media literacy is critical in anticipating the negative impacts of media.

Media literacy is a practice of audience skills or competencies in using and communicating with the media. From time to time, media literacy experiencing changes and adjustments, starting from media literacy in print media eras, media literacy in electronic eras, and then media literacy in new media or digital eras, which uses and combines audio, visual, and other formats (Guntarto, 2016). The objective of media literacy is to help people develop a better understanding and control against the influences of media in their daily life. The control begins by comprehending the differences among media messages, whether they can improve a person's quality of life or "destroy" one's life (Rahmi, 2013).

Nupairoj (2016) believes that the ecosystem of media literacy can help enhance media literacy education to be more effective in changing learners' behaviour and create a media literacy society. It also offers new knowledge that applies to other developing countries. The current reality of mass media in Indonesia, especially television, is considered to "hinder cultural reconstruction'. Even though many experts said that there is a selective audience 
towards messages from mass media (television), however, if look at the situation in Indonesia, where most of the population live in remote areas, low education, little social control, then the negative impacts are more influential than positive impact (Gafari, 2008; Suryadi, 2013).

Television can influence consumerism as a result of the research. Sukmana et al. (2018) prove that advertising creativity, message quality, and frequency of delivery are essential factors that can partially influence consumers to make purchases. According to Tarigan et al. (2016), children who watch television continuously will have less time to do activities with other people and, more importantly, spend their time doing homework or other assignments. However, ironically, many parents who gave up their care to television as a substitute for the role of parents in accompanying children's daily lives (Dewi Juni Artha, 2016). Television often broadcasts content that is not child-friendly, but also on radio, song lyrics are often played, whose contents are not following norms and rules because they contain sensual elements and other harmful things. This is where parents have an essential role in introducing basic literacy to children (Senechal \& LeFerve, 2002).

Based on the facts above, broadcasting regulator roles in Indonesian are crucial in keeping an eye on broadcast content. The broadcasting regulator in Indonesia, Regional Indonesian Broadcasting Commission (KPID), is responsible for a healthy broadcast content in West Java. KPID is a form of public participation in guarding broadcast media content following the mandate of broadcasting law No. 32 of 2002 (Presiden Republik Indonesia, 2002). KPID must have the ability of media literacy in doing duties and authority. One of the Human Resources components in KPID is broadcast monitors. Hence, these broadcast monitors must have media literacy abilities to help the performance of KPID in doing their duties and authorities. Why does broadcasting media need to be watched? Gerard J. Waldron (in Rochim, 2007) explain that as the broadcasting regulator, it is essential to protect public interests, such as child protection and family norms. Because of this more substantial influence, the government makes regulations for broadcast media much "stricter" when compared to print media.

Therefore, the researchers are interested in conducting studies regarding the media literacy ability of broadcast monitors in carrying out their duties to monitor healthy broadcast content to contribute towards the performance of KPID in West Java. The research was conducted through a quantitative descriptive research method. The author will map the extent to which accessibility, analytical skills, evaluation skills, and communication skills of broadcast monitors in supporting concern for healthy broadcasts.

\section{LITERATURE REVIEW}

\section{a. Media Literacy}

Nowadays, media technology has taken part in specific roles in society. Along with the development of communication technology, there are several consequences, both positive and negative connotations, on the influence of communication media technology use. This phenomenon is getting lively when mass media compete with each other in providing information services to consumers. High penetration of communication media has increasingly challenging to control. Now, the public is not only getting information, knowledge, and entertainment but can interact directly. At the same time, media instil new ideological values in the form of lifestyle, consumer culture, and models of imitating attitudes and behaviour of certain artists/actors popularized by media. Therefore, it is time for media penetration vigorous and free to be balanced with media literacy as a culture of countering 
negative impacts of media. Besides, media literacy also aims to protect vulnerable and vulnerable audiences against the impact of media penetration of new media culture.

Dennis McQuail (2010) said, media literacy had grown since the 1970s, when the term of social construction was born, which made the impact of media comprehensible. The media have great significance because of their ability to construct reality. It has a twofold origin: (1) the media practices social construction through the framing of reality, in a predictable and patterned way, and (2) the audiences construct themselves on the frame of social reality presented by the media and its environment. This concept promotes the awareness of the audience's ability to choose media content freely (Angeliqa \& Sarwono, 2019).

The importance of media literacy is not only the ability to read and write, but literacy can mean literacy in technology, politics, critical thinking, and being sensitive to the environment. According to Wells, there are four levels of literacy, which are performative, functional, informational, and epistemic. The first level of literacy is simply able to read and write. The second level of literacy shows the ability to use language for life purposes or skills for survival (such as reading manuals, filling out forms, etc.). The third level of literacy is showing the ability to access knowledge. The fourth level of literacy shows the ability to transform knowledge. Literacy is a life skill that makes humans function optimally in society. Life skills come from the ability to solve problems through critical thinking activities. Besides, literacy is also a reflection of cultural mastery and appreciation. A cultured society is a society that instils positive values as an effort to actualize itself. Self-actualization is formed through interpretation, such as an activity of seeking and building meaning in life. This can be achieved through good literacy mastery (Irianto \& Febrianti, 2009).

Generally, media literacy is the ability to access, analyze, evaluate, and create messages in various forms (Aufderheide, 1993; Christ \& Potter, 1998). These four components-access, analysis, evaluation, and content creation-together constitute a skillsbased approach to media literacy. Each component supports the others as part of a nonlinear, dynamic learning process consists of learning to create content helps one to analyze, produced professionally by others, using skills in analysis and evaluation open the doors to new uses of the Internet, expanding access, and so forth (Livingstone, 2004).

Yodiansyah (2018) found that mass media literacy contribution is beneficial for human life provided that media literacy is used healthily and regularly. Research in Malaysia found that "media literacy can motivate its users to understand effects in the future. A national digital media literacy program that advances digital storytelling is an essential step in addressing initiatives that aim to enhance young people's media practice. Continuous dialogue, policy support, and research activities must persist in creating a digital media learning environment where young people can access, understand, evaluate, collaborate, and create lifeworld experiences in holistic ways" (Syam \& Nurrahmi, 2020).

Media literacy may be defined as the ability to access, analyze, and evaluate the power of images, sounds, and messages which we are now being confronted with daily and are an essential part of our contemporary culture, as well as to communicate competently in media available on a personal basis. Media literacy relates to all media, including television and film, radio and recorded music, print media, the Internet, and other new digital communication technologies. Media literacy aims to increase awareness of the many forms of media messages encountered in their everyday lives. It should help citizens recognize how the media filter their perceptions and beliefs, shape popular culture, and influence personal choices. It should empower them with critical thinking and creative problem-solving skills to make them 
judicious consumers and information producers. Media education is part of the basic entitlement of every citizen, in every country in the world, to freedom of expression and the right to information, and it is instrumental in building and sustaining democracy" (Bulger, 2012).

The media literacy framework of the initial report included five main categories organized under Individual Competencies and Environmental Factors. These categories included: use skills (technical), critical understanding, communicative abilities, media literacy context, media availability, which can be described below.

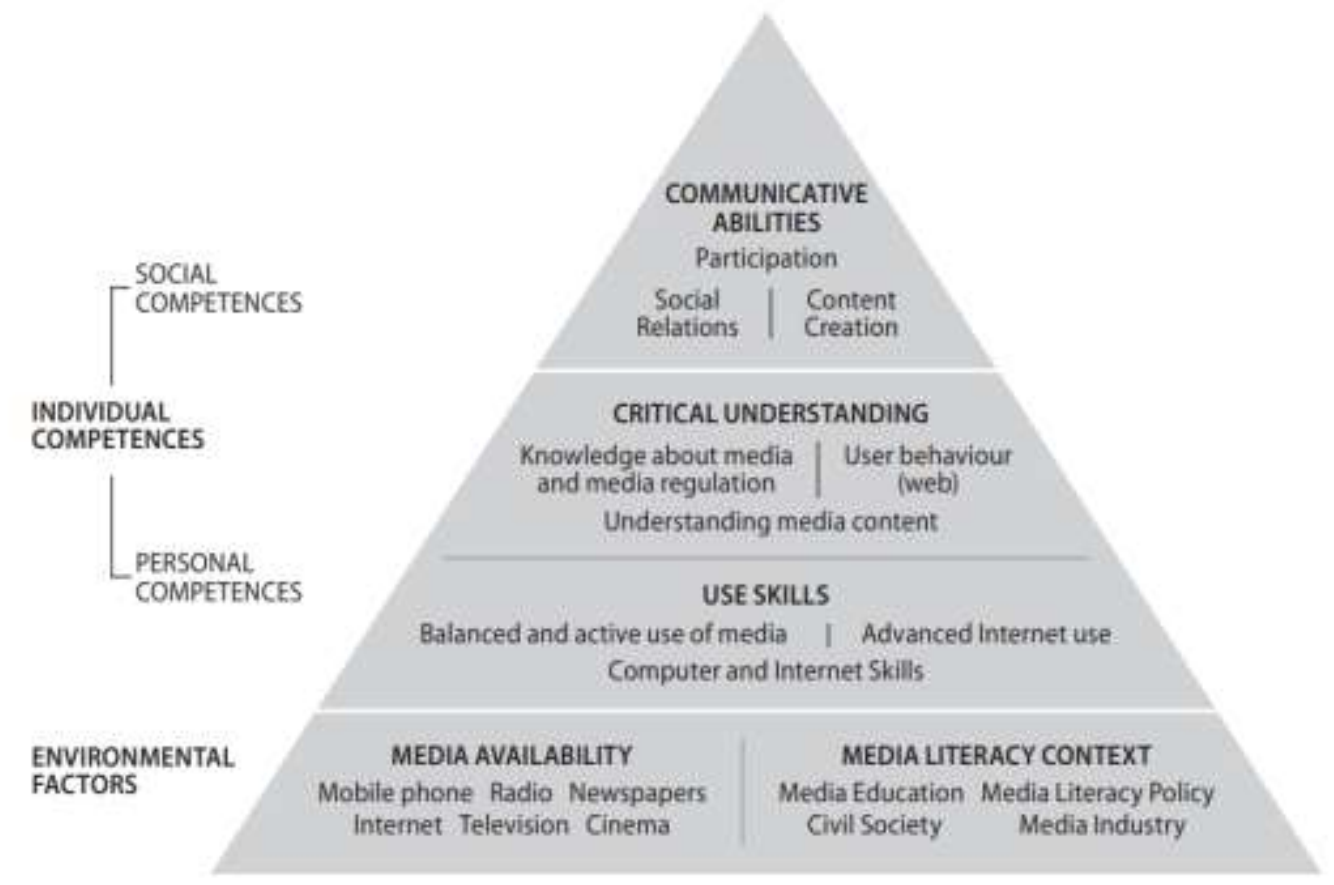

Figure 1: Initial media literacy framework (Celot \& Pérez Tornero, 2009).

Media literacy experts acknowledge that narrowing this complex concept into discrete, measurable components is challenging (Buckingham, 2004) and accounting for demographic differences and the variety of contexts in which media literacy is enacted exceeds what can reasonably be accomplished in a single study.

\section{b. Broadcasting Regulation in Indonesia}

Broadcasting regulations in a country are critical because broadcasting requires special treatment. After all, four critical considerations: (1) children have access to radios and in many cases are unsupervised by parents; (2) radio receivers are in the home, a place where people's privacy interest is entitled to extra deference; (3) un-consenting adults may tune in a station without any warning that offensive language is being or will broadcast; and (4) spectrum space is scarce, the use of which the government must therefore license in the public interest. Of particular concern to the commission and parents is the first point regarding the use of radio by children (Steele, 2010). 
In the democratic political system during the Reformation era in Indonesia, there have been several attempts to revise broadcasting regulations. Wahyuni (2006) mentioned that there were several actors, such as policymakers, broadcast industry actors, and stakeholders, as well as civil society organizations that contributed to the drafting of new broadcasting law (1998-2002). Then, the Law of Broadcasting of 2002 passed by the House of Representatives (DPR). The main feature of this Broadcasting Law is that it introduces the Indonesian Broadcasting Commission (KPI) as an independent government commission to regulate broadcasting practices. This fact shows that government involvement in broadcasting supervision is reduced because its authority is under the KPI domain. Nevertheless, today, the role of KPI has been limited by the Ministry of Communication and Information. As a result, KPI now only has limited authority to regulate broadcasting in Indonesia (Kitley, 2008; Setianto, 2018).

Normatively, the institution that regulates broadcasting regulations in Indonesia is KPI, as regulated in Law no. 32 of 2002. Center KPI and Regional KPI have functions and authorities based on Law Number 32 the Year 2002 Article 8, are: (1) KPI as a form of social participation, functions to accommodate aspirations, and represent interests of society for broadcasting. (2) In doing its functions as referred to in paragraph (1), KPI has authorities: a. Determine broadcast program standard, b. Formulate regulations and establish for broadcasting behaviour guidelines, c. Oversee implementation of regulations and broadcasting behaviour guidelines also broadcast program standards, $d$. Provide sanctions for violation of regulations and broadcasting behaviour guidelines also broadcast program standards, e. To coordinate and or collaborate with government, broadcasting institutions public (Presiden Republik Indonesia, 2002).

Based on this law, the broadcasting behaviour guidelines and broadcast program standards (P3SPS) is a control or regulatory device prepared by Indonesian Broadcasting Commission to be used as a reference in all broadcasting operations in Indonesia. This Broadcasting Behaviour Guidelines and Broadcast Program Standards (P3SPS) are made in the context of regulating the behaviour of broadcasting institutions in broadcasting all broadcast content. This Broadcasting Behaviour Guidelines and Broadcast Program Standards (P3SPS) designed with due observance of various forms of Code of Ethics and Program Standards that have been developed by the professional community in broadcasting and mass media in Indonesia so far, such as the Indonesian Journalist Code of Ethics, Broadcast Radio Professional Standards and Broadcast Program Guidelines. Besides, these Guidelines refer to various laws and regulations in force in Indonesia: Criminal Code, Press Law, and Film Law (Regional Indonesian Broadcasting Commission, 2018).

\section{METHODOLOGY}

This study used a descriptive analysis method with a quantitative approach. Descriptive analysis method refers to research projects conducted to determine the existence of independent variables, either in one or in more variables (independent variables) without making comparisons and looking for the relationships with other variables (Sugiyono, 2018; Suharsimi \& Arikunto, 2010).

The study population showed that volunteers, also known as broadcast monitors, were recruited by the Regional Indonesian Broadcasting Commission (KPID) of West Java Province in 2018. The volunteers consist of broadcast monitors from five regions in West Java (Sumedang, Subang, Karawang, Bogor, and Bandung) with the following details: 


\begin{tabular}{llc}
\multicolumn{3}{c}{ Table 1: Population sample } \\
\hline No. & \multicolumn{1}{c}{ Territory } & Volunteer \\
\hline 1. & Sumedang & 30 \\
2. & Subang & 30 \\
3. & Karawang & 30 \\
4. & Bogor & 30 \\
5. & Bandung & 20 \\
& Total & 140 \\
\hline & Source: KPID West Java 2018
\end{tabular}

The research sample used a total sampling of 140 people. The data collection technique was conducted by distributing research questionnaires. The questionnaires are supporting data, related to the literacy ability of broadcast monitoring media. The questionnaires are a data collection technique, which is done by giving a set of questions or written statements to respondents to answer (Sugiyono, 2018). The questionnaires in this study were proposed to measure media literacy levels with a closed and comprehensive answer pattern because certain written answer choices were provided. The data obtained will be analyzed, presented, and evaluated so that they have meaning.

In this study, data analysis used descriptive statistics, which is to calculate the frequency and percentage of responses from respondents presented in the form of a working table and analyzed descriptively.

\section{RESULTS \& DISSCUSSION}

In carrying out its duties, functions, and authority to develop healthy, intelligent, and educating broadcasting in West Java Province, the West Java KPID provides opportunities for public participation by forming healthy broadcasting care communities. The purpose of this program is to form a community of people from various social strata to become partners of the West Java KPID in realizing community participation to monitor and supervise television and radio broadcasts in the West Java region. Besides, the activity also aims to fulfil the obligations and duties of the KPID in terms of monitoring the contents of the broadcast through direct monitoring activities involving the public called "Broadcast Monitors" consisting of components environmental of higher education, senior high school, official education, pesantren (boarding school), mosques and recitation group, and mass organizations in West Java.

Based on the field findings, the researchers grouped discussion of media literacy capabilities of broadcast monitoring into four qualifications as stated in the concept of media literacy in the literature review, namely the ability to access, analyze and evaluate the power of images, sounds, and messages and to communicate competently in media available on a personal basis.

\section{Accessibility Abilities of Broadcast Monitors}

Information accessibility is the accuracy and speed of the respondents in accessing, searching, and getting the required information. According to Hadiyanto (2009), media accessibility is measured by ownership of modern mass media such as newspapers, radio, and television. Their use includes the frequency of use, the time typically used to access the media, and the types of programs accessed. Accessibility of communication media is one element of communication behaviour (Nuraini, 2016). 
Thus, the ability of accessibility in research related to media exposure does not only concern whether someone has felt the presence of mass media but also whether someone is genuinely open to the message conveyed by the media. Exposure is an activity of listening, seeing, and reading media messages or having experience and attention to those messages which can occur to individuals or groups. Media accessibility is the ability to use media, media type, frequency, and duration (longevity). Therefore, in measuring accessibility abilities in this research, the frequency of media use includes the number of times someone uses media. Figure 2 shows how the frequency of broadcast monitors media uses in KPID West Java.

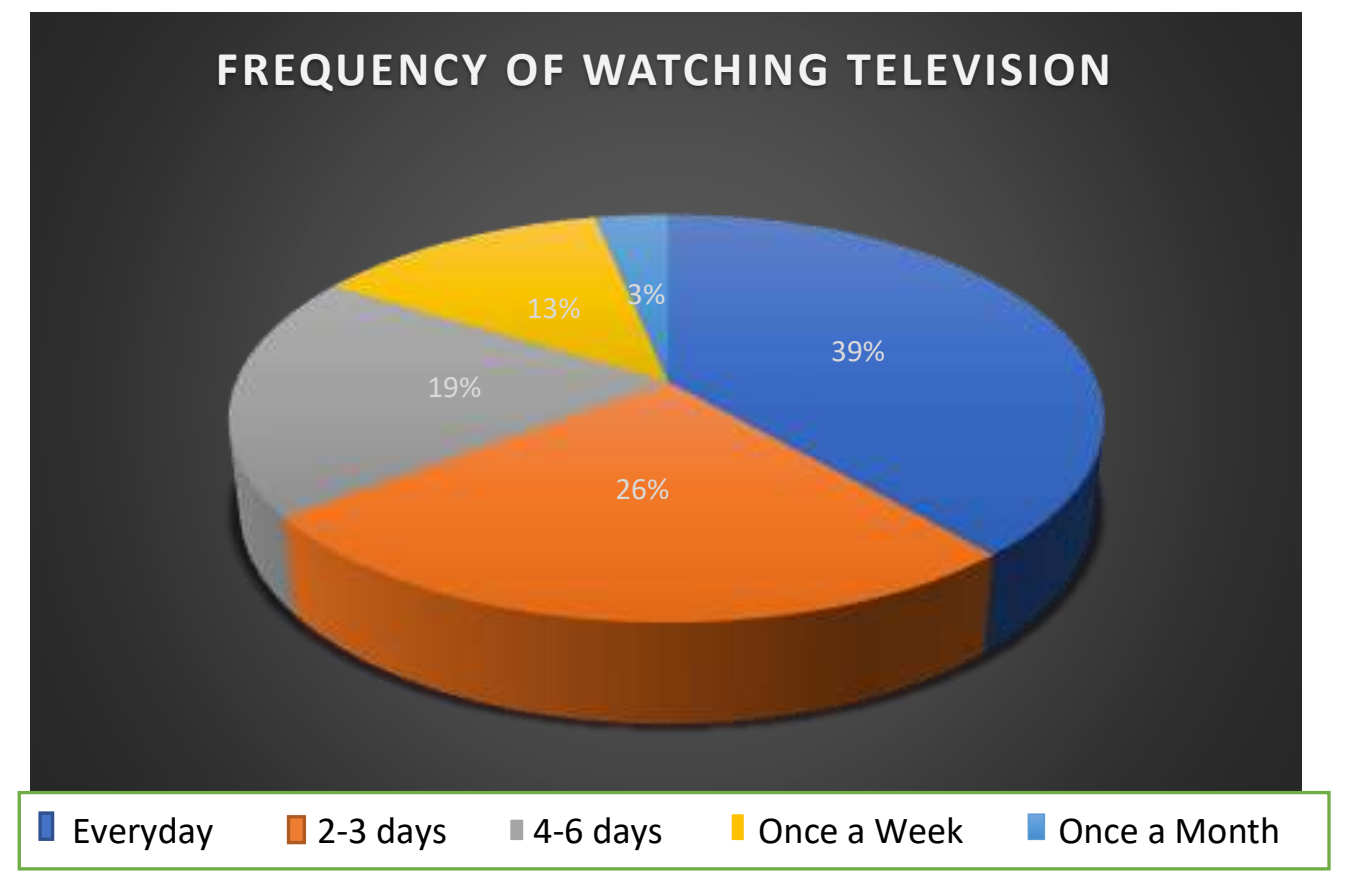

Figure 2: Frequency of Watching Television

Source: Research Questionnaire 20

About 39\% of audiences watch television every day, so, in general, the audience is hit by television media with varying degrees, and daily exposure still dominates. This condition illustrates that broadcast monitors are exposed to television media with adequate intensity because they are exposed almost every day. When audiences are exposed to the media frequently, then the media literacy indicator is that broadcast monitors know how the media operate. Knowledge of the media will be the basis for understanding media content deeper.

In measuring media exposure, it also examines the question on how the behaviour of media use including how long the audience joins a media (how many hours a day); or how long the duration (in minutes) the audience use to follow a program (audience's share on the program). Figure 3 explains the duration of watching television among audience. 


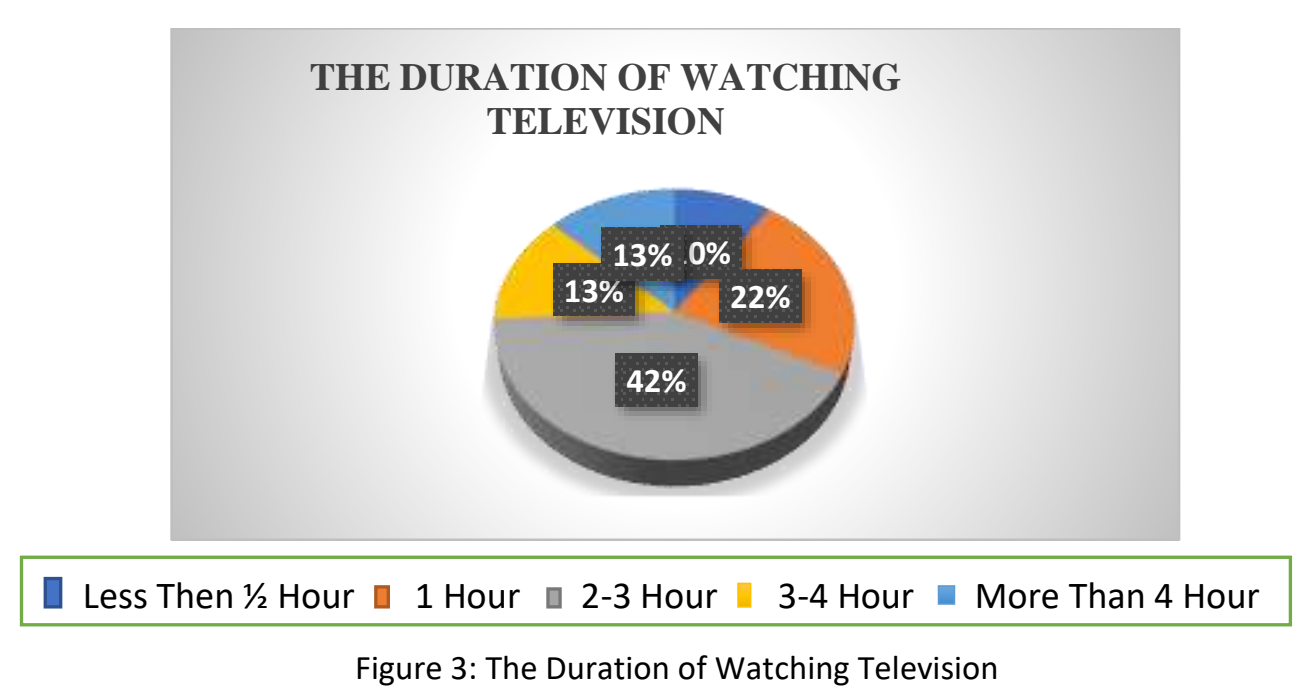

Source: Research Questionnaire 2019

In general, $42 \%$ of the audience watch television 2-3 hours a day, $22 \%$ of the audience used 1 hour a day, 13\% of the audience used 3-4 hours a day and more than 3 hours a day in the same percentage. Thus, the audience in terms of quantity has watching ranges between 1-3 hours a day, which is quite dominating. Watch duration is an indicator where it is not just intensity but rather the quality of digesting media messages over a certain period. The results of the research on the level of television viewing duration of broadcast monitors are relatively high in the range of 1 to 3 hours. This condition is enough to illustrate that broadcast monitors have sufficient time to understand the media's message.

The above conditions are in line with the phenomenon that the current high penetration of communication media, where the impact is increasingly challenging to control. Now, the audience is not just getting information, knowledge, and entertainment, but can interact directly with the media. Simultaneously, the media instil new ideological values in the form of lifestyle, consumer culture, and models of imitation of the attitudes and behaviour of figures popularized by the media. Then, the more intensive and free media penetration must be balanced with media literacy as a culture of resistance to the negative impact of the media. Media literacy is an ability that must be possessed by anyone. This is important because not all media content is beneficial to the public. Many of them do not educate and only prioritize the interests of media owners or managers to get the most profit. Media literacy intends to equip audiences with the ability to sort and assess media content critically so that audiences are expected only to utilize media content under their interests. This is in line with what was stated by Potter:

The mass media continually exert all kinds of direct and indirect influences on individuals and society. These influences can immediately trigger effectscognitively, attitudinally, affectively, physiologically, and/or behaviourallyduring exposure to a media message or gradually build up over time by shaping and reinforcing knowledge structures, beliefs, and habits. A second assumption is that many of these naturally occurring effects are negative, that is, are harmful to individuals, or at least not useful to the individual positively or constructively. Third, it is assumed that one can construct interventions that help people avoid these adverse effects in their everyday lives. Building 
on these assumptions, the purpose of media literacy interventions is to target a potential negative media effect and to either innoculate people against such an effect occurring or to counter the already existing negative effect. Thus, interventions are designed for the avoidance or the removal of a naturally occurring negative effect that results wholly or in part from the influence of messages from the mass media (Potter, 2010).

\section{Analytical Skills of Broadcast Monitors}

Understanding media literacy is also measured through the analysis ability of the individual to digest the media. In this regard, an individual with an adequate understanding of media literacy must be able to recognize an event or the information that surrounds him comprehensively, so to complement the media literacy ability in this study. Figure 4 revealed the analysis ability of the community.

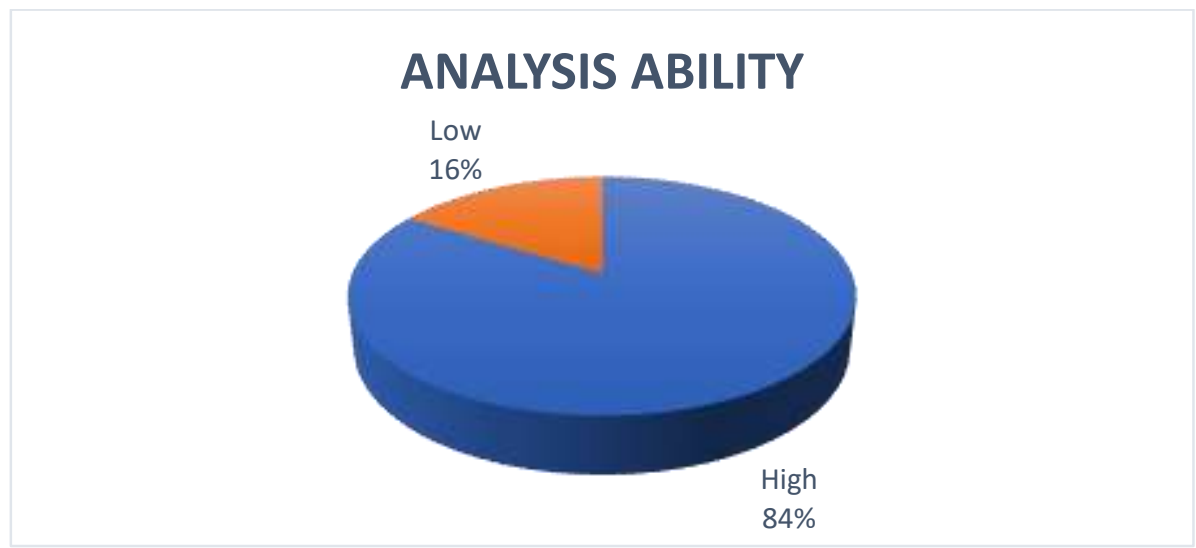

Figure 4: Analysis Ability

Source: Research Questionnaire 2019

The analysis ability of the respondents to the media, hitting them was very high. This is evident from Figure 4 that $84 \%$ of respondents had high media analysis skills, while only $16 \%$ had low analytical skills. This indicates that broadcast monitors can analyze media messages comprehensively. Individuals who can analyze mean that they can see further the form and structure of messages. They can use artistic, linguistic, social, political, and economic concepts to understand the context of messages. They use knowledge and experience to interpret messages. In this research, volunteers were able to analyze television broadcast programs as a whole in what the context of the content of media was delivered. Related to this ability, it is relevant to individual skills in cognitive thinking. The results of experimental studies conducted in Malaysia for adolescents show that cognitive thinking skills and educational background of adolescents have influenced the interpretation and understanding of film (Ling et al., 2019). The adolescents' interpretation and understanding are influenced by individual factors (educational background and cognitive thinking), media texts (media aesthetics), and external factors. Thus, individual factors are a key aspect of media literacy for interpreting messages critically. 


\section{Evaluation Ability of Broadcast Monitors}

Evaluation ability is an action or process to determine the values of something. In this case, evaluation determines whether something has value or not. In media literacy, the main focus of analysis is the critical evaluation of messages. Media literacy understands sources and communication technology, codes used, messages produced and selection, interpretation, and impact of these messages. So, the next step in this research is to measure the level of respondent's evaluation ability to media exposure as seen in the image below:

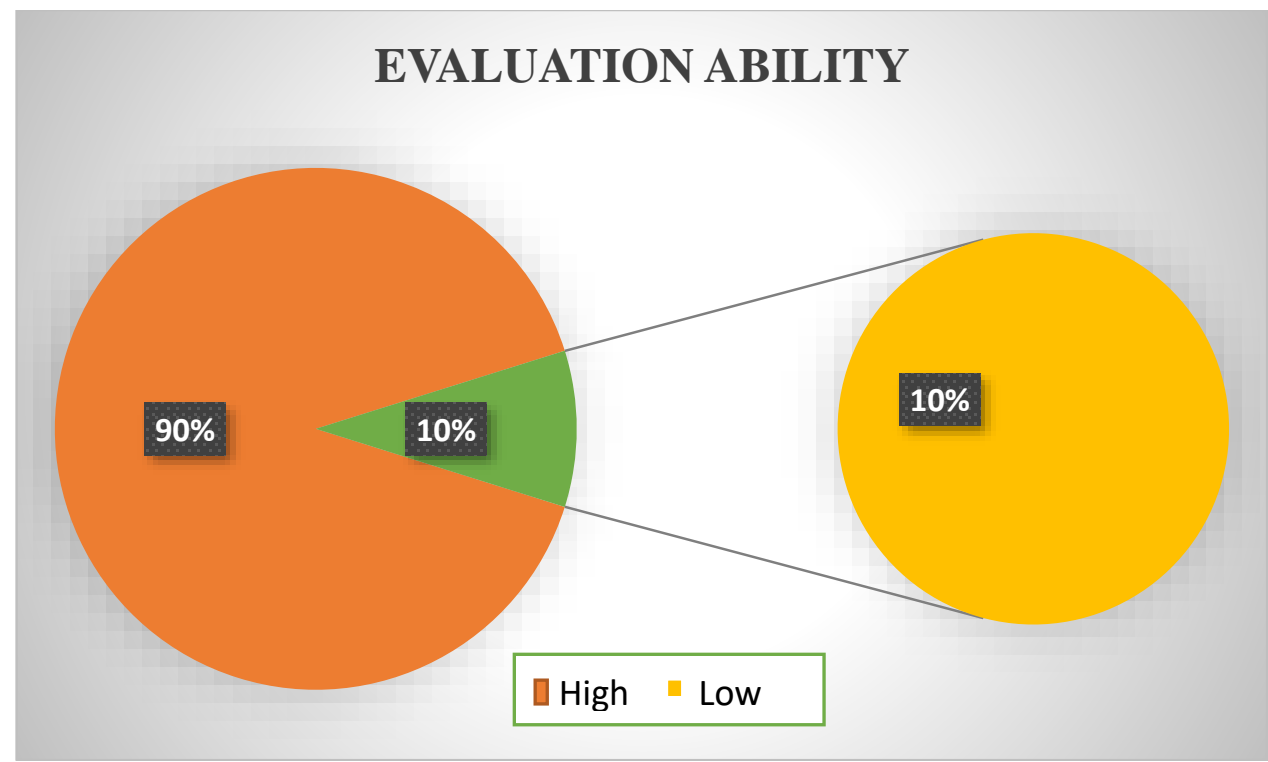

Figure 5: Evaluation Ability

Source: Research Questionnaire 2019

In line with analytical skills, the evaluation ability of volunteers who are the object of this study also has a very high percentage, with $90 \%$ of the audience having the evaluation ability of high categories, and the rest is low categories. This means that broadcast monitors can assess the content of media by comparing it with specific criteria. In evaluating messages, it is not only the knowledge that must have the broadcast monitors volunteers but also those related to emotional, moral, and aesthetic issues. When someone evaluates a message, then he can relate the message to his experience and then assess the truth, quality, and relevance. He can reward and get pleasure from interpreting the message, responding to the complex message through writing or speech, and assessing its values based on ethical or religious principles.

\section{Communication Ability of Broadcast Monitors}

Communication ability is also important in understanding media literacy. This ability is essential because it concerns what an individual will do after he understands, criticizes, and evaluates. Individual steps to communicate what they already know based on the results of the research can be described as follows: 


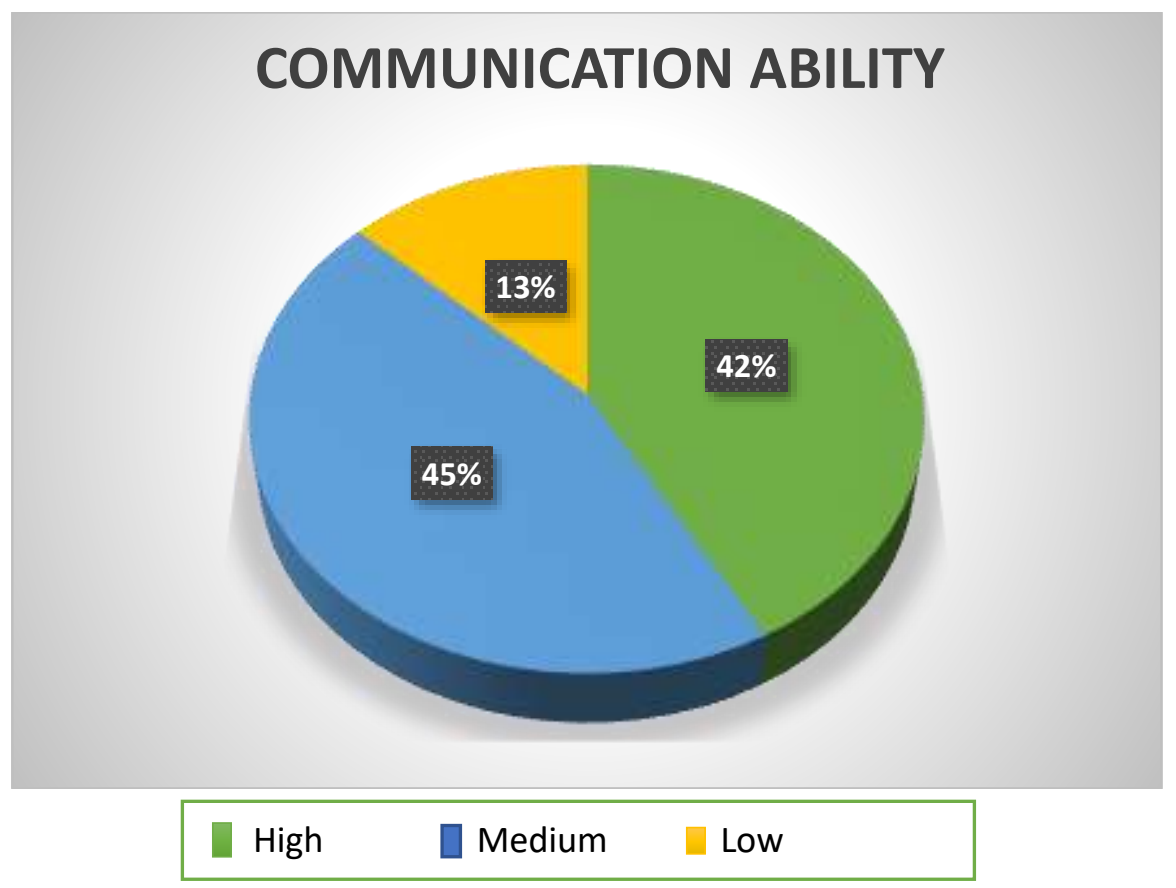

Figure 6: Communication Ability Source: Research Questionnaire 2019

Communication ability in the context of understanding media literacy among respondents of this research is at the same level on high and medium categories. Only $13 \%$ of the respondent is in a low category.

Media message has meanings on the surface (explicit) and below the surface (implicit). Individuals with low media literacy capabilities can only see meanings on the surface. In this condition, the media holds control because it determines the meaning, and the meaning has never been explored further. If a person's media literacy capability is high, he can construct interpretations differently from what the media presents. Thus he did not merely accept what was conveyed by the media. Having control over the media does not mean that someone can change the media but to change on how we expose ourselves to the media and change the effects of the exposure on us. This is reinforced by the statement that media literacy can build a strong filter, both in themselves and in the people in their environment, so they are not influenced by the media (Rachmiatie \& Suryadi, 2009).

High media literacy capability will affect the critical strength of broadcast monitors in viewing television broadcast content. When broadcast monitors have high critical power, he will analyze, evaluate, and communicate the content's findings associated with applicable norms. In this study, based on data found, the media literacy capability of broadcast monitors is very high, meaning that broadcast monitors have adequate knowledge about the messages conveyed by television media. This knowledge becomes the basis for broadcast monitors to analyze what they know from media messages related to broadcast regulations. Broadcast monitors understand the contents of television media, which are linked to broadcasting laws and the standard code of conduct of broadcast programs so that volunteers are also able to see comprehensively by assessing whether a message is appropriate or inappropriate to be displayed on a television. The step that is needed when the broadcast monitors know, analyzes, and evaluates is whether the broadcast monitors intends to make a complaint about the inappropriate broadcast content to the KPID of West Java. Based on the results of 
research, broadcast monitors have aspects of communication behaviour with high and medium categories to submit complaints related to the broadcast content to the authorities, in this case, the KPID of West Java.

Thus, the media literacy capability of broadcast monitors can help regulators' performance in carrying out their duties to monitor broadcast content. Arya et al. (2019) illustrate the urgency of media literacy as "The level of education is revealed to have a significant effect as a moderating factor towards the acceptance of health information and media literacy in general, which in turn enhances the preventive behaviours on cervical cancer issues. These findings confirm that higher education is associated with ancillary benefits, one of which is the understanding of health issues and the result improved preventive behaviour outcomes". It turns out that the level of understanding of media literacy, in turn, increases prevention behaviour in the problem of cervical cancer, understanding of health problems and can improve prevention behaviour. In the study of media literacy and health, for example, Nielsen-Bohlman et al. (2004) defined health literacy as a degree to which individuals can obtain, process, and understand necessary information and services needed to make appropriate decisions about health (Eng et al., 2018).

According to Kelner (in Oso \& Omoye, 2018), anticipating this media's influence emphasizes the role of media and information literacy that more and more media help build our image and understanding of the world. Another challenge is how to teach media literacy in multicultural societies and make people aware of injustice based on inequality and discrimination in gender, race, and class. This reinforces the importance of media literacy.

In the context of the study, this paper has the same idea to strengthen the importance of media literacy capabilities because adequate media literacy capabilities will increase the critical power of volunteers so that volunteers will convey monitoring of broadcast content, which is not under applicable norms to the KPID. The results of this monitoring will then be processed by the KPID and then whether broadcasting institutions get sanction or not. The sanctions mechanism is illustrated in Figure 7.

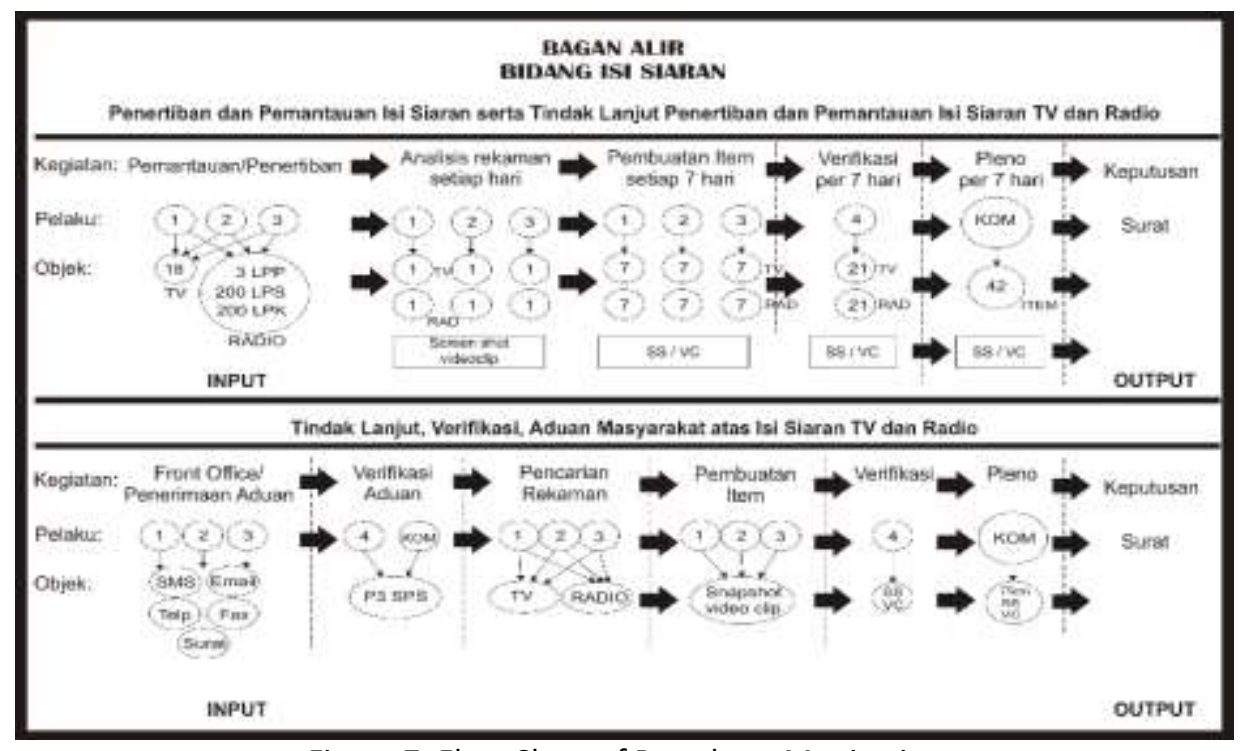

Figure 7: Flow Chart of Broadcast Monitoring Source: Research Questionnaire, 2019 
The KPID of West Java carries out its duties in guarding broadcast content using several methods, namely through (1) Monitoring with a broadcast monitoring tool that is carried out for 24 hours; (2) Analyzing control by taking broadcast recordings at broadcasting institutions in West Java; (3) Community participation through several means of complaints that can be done by the community from various components.

In the flowchart above, the process starts with the indication of findings through monitoring and supervision tools, control, and public complaints. Analysis of recordings is carried out daily by monitoring staff, making items, verifying by the coordinator of the broadcast content field, then plenary meeting on broadcast content to determine sanctions to be given to broadcasters. The results of the plenary meeting are recorded on the minutes, which must meet the quorum of meeting participants, and then letter sanctions are posted to broadcasters through either the Central KPI or directly to broadcasters.

One of the kinds of community participation in encouraging broadcasting in West Java is the community that can make complaints related to violations committed by broadcasting institutions. This is where the role of broadcast monitors becomes vital as a material supplier of infringing broadcast content findings so that it can assist the KPID of West Java in carrying out its duties to oversee broadcasting institutions.

Some of the facilities prepared to get a response from the community, including broadcast monitors, to make complaints. From several complaint media, the most were sent through SMS. Besides, through the complaint box in the KPID of West Java or in places when the KPID conducts activities such as at the West Java development exhibition or during media literacy socialization. Besides, complaints were also submitted by the public through online media such as Facebook, Instagram, Twitter, Fanpage, WhatsApp, and also email. Other media used as a means of complaints are by mail or by express delivery, and some people come directly to the KPID office to make complaints related to the broadcast content.

This public participation is essential to encourage the performance of the KPID following the broadcasting law Number 32 of 2002 in carrying out the duties and authorities of the KPI/KPID as listed in Article 55 paragraph 2 is to provide administrative sanctions in the form (Presiden Republik Indonesia, 2002) of: (1) written warning; (2) a temporary ban to broadcast the program after going through certain stages; (3) Discussion of duration and time of broadcast; (4) Administrative Fine; (5) a ban to broadcast activities for a particular time; (6) no extension of the broadcasting operating license.

In this research, based on data that is found when it is related to the theory in the Initial media literacy framework assumed that there are environmental factors that exist in this framework, are media availability is television, media used and accessed by broadcast monitors. The context factor of media literacy is the individual ability of broadcast monitors. Both grouped as personal competence, are the ability of accessibility, analysis, and evaluation, while social competence is communication capabilities of broadcast monitors. If mapped, the result of this research accordance with media literacy theory used, so: 


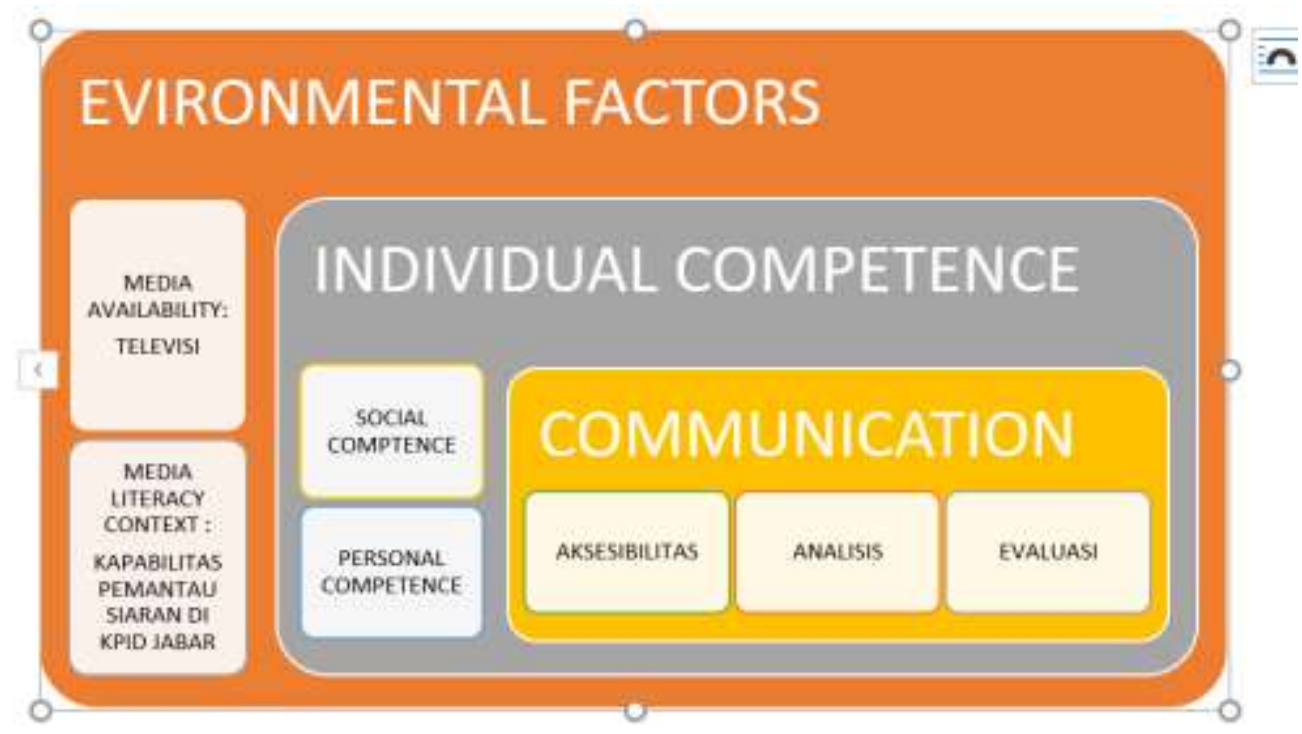

Figure 8: Media Literacy Capabilities Model of Broadcast Monitors

In the step of skill use, broadcast monitors active use television media, then there is a process of critical understanding by understanding media content and broadcast media regulations. In the next step, there is a process of participating in broadcast monitoring through communicative abilities to KPID West Java. Based on this research, broadcast monitors have a communication behaviour aspect by high and low categories to submit a complaint related to broadcast content to KPID West Java.

Hobbs's research also states the importance of media literacy even in the context of educational institutions "teachers and other educators both in and out of school can employ the evidence to develop new structures and models that value the tenets of media literacy education, put into practice the strong sense critical thinking skills, and encourage the expressive abilities of young people" (Jensen \& Kazemek, 2008). Even research that has been done in India describes that "media literacy and media education are very much related and required in today's life and proper understanding of these concepts are very much necessary in order to use the different media of information, pin pointedly get the required information, decipher and understand it, analyze and critically examine it for the optimum utilization" (Ghosh et al., 2015).

The study concludes that students in secondary schools in Lagos, Nigeria, have some required information literacy skills. Also, the information skills of the Secondary School Students contributed significantly to the use of media resources available to them. Besides, it was discovered that there was a significant relationship between the level of information literacy skills possessed by the students and the use of media resources available to them. This translates that for effective use of media resources among the students, information literacy skills are required (Amusan \& Lawal, 2020).

In the context of this research, it also strengthens the importance of media literacy capabilities because adequate media literacy skills will increase the critical power of broadcast monitors so that broadcast monitoring that is not following applicable norms will be reported to KPID West Java. KPID West Java will then process the results of this monitoring under applicable regulations. 


\section{CONCLUSION}

The ability of broadcast monitors regarding accessibility to media, which includes television viewing frequency and duration, shows that the audiences are exposed to various levels of television media and daily exposure, which is still dominating. This condition illustrates that broadcast monitors are exposed to television media with sufficient intensity because they are hit by them almost every day. Meanwhile, the duration of watching broadcast monitoring television is relatively high in the range of 1 to 3 hours per day.

The respondents' ability to analyze the media is very high. This is evident that $84 \%$ of broadcast monitors have high media analysis skills, while only $16 \%$ have low analytical skills. In line with the analytical skills, the monitoring staff's evaluation ability, which is also the object of this research, has a very high percentage where $90 \%$ of the audiences can evaluate the high category and $10 \%$ for the low category. Meanwhile, communication skills in the context of understanding media literacy in the respondents of this study were in the high and moderate categories, which were not so different. The high category is valued at $42 \%$, while the low category is $45 \%$, and only $13 \%$ is in a low category.

This research has theoretical and practical implications that the literacy ability of broadcast monitoring media can increase the level of complaints related to broadcast content and the number of broadcast violation findings reported to the West Java Regional Indonesian Broadcasting Commission, which later will be sanctioned by broadcasting institutions. Suggestions for further research, it is necessary to research the correlation of media literacy skills with the level of awareness of broadcasting institutions as well as complying with the regulations related to broadcast content.

\section{BIODATA}

Dedeh Fardiah is an Associate Professor at the Communication Faculty of Universitas Islam Bandung. Her research interests include media, broadcasting, internet and media literacy. She has experience as Chairman of the West Java Regional Broadcasting Commission (KPID). Email: dedeh@unisba.ac.id

Ferry Darmawan is an Associate Professor at The Communication Faculty of Universitas Islam Bandung. His research interest is the field of Visual Communication, ICT, New Media and Politics. Email: ferry@unisba.ac.id

Rini Rinawati is an Associate Professor at The Communication Faculty of Universitas Islam Bandung. Her research interest is in the area of media literacy, Communication around the family, Women Empowerment and Child Protection. Email: rini.rinawati@unisba.ac.id 


\section{References}

Amusan, B., \& Lawal, O. W. (2020). Information literacy skills and media resource utilisation among secondary school students in Lagos state, Nigeria. Library Philosophy and Practice (e-journal), 4109, 3-14. Retrieved from https://digitalcommons.unl.edu/libphilprac/4109/

Angeliqa, F., \& Sarwono, B. K. (2019). Family disposition related to media literacy for advertisements of children's snacks in the media. Jurnal Komunikasi: Malaysian Journal of Communication, 35(4), 258-271. https://doi.org/10.17576/JKMJC-20193504-16

Arya Dharma Shinta, Mohd. Azul Mohamad Salleh, \& Mohd. Nor Shahizan Ali. (2019). Analysis of the moderating effect of media literacy on cervical cancer preventive behaviours. Jurnal Komunikasi: Malaysian Journal of Communication, 35(1), 156-170. https://doi.org/10.17576/jkmjc-2019-3501-11

Buckingham, D. (2004, January). The media literacy of children and young people: A review of the literature. Ofcom. Retrieved from http://www.ofcom.org.uk/advice/media_literacy/medlitpub/medlitpubrss/ml_childr en

Bulger, M. E. (2012). Measuring media literacy in a national context: Challenges of definition, method and implementation. Medijske Studije, 3(6), 83-104.

Celot, P., \& Pérez Tornero, J. M. (2009, October). Study on assessment criteria for media literacy levels: A comprehensive view of the concept of media literacy and an understanding of how media literacy levels in Europe should be assessed. European Association for Viewers' Interests, 1-92.

Eng May Chuen, Edwin Michael, \& Teh Boon Teck. (2018). The role of media socialization agents in increasing obesity health literacy among Malaysian youth. Jurnal Komunikasi: Malaysian Journal of Communication, 32(2), 691-714. https://doi.org/10.17576/jkmjc-2016-3202-34

Ghosh, S., Bagchi, A., \& Das, P. S. (2015). The awareness of media literacy and media education among the users of university library in India: A case study. International Research: Journal of Library \& Information Science, 5(2), 329-340.

Jensen, A. P., \& Kazemek, F. E. (2008). Professional resources. Journal of Adolescent \& Adult Literacy, 52(3), 261-265. https://doi.org/10.1598/jaal.52.3.10

Livingstone, S. (2004). Media literacy and the challenge of new information and communication technologies. The Communication Review, 7(1), 3-14. https://doi.org/10.1080/10714420490280152

Nuraini, S. S. S. (2016). Aksesibilitas media komunikasi dengan kompetensi peternak sapi potong di Kabupaten Bojonegoro. Indonesia: Institiut Pertanian Bogor.

Oso, L., \& Omoye, A. (2018). Media and information literacy and democracy in a multi-ethnic society. Jurnal Komunikasi: Malaysian Journal of Communication, 30(1), 170-186. https://doi.org/10.17576/jkmjc-2014-3001-09

Potter, W. J. (2010). The state of media literacy. Journal of Broadcasting and Electronic Media, 54(4), 675-696. https://doi.org/10.1080/08838151.2011.521462

Presiden Republik Indonesia. (2002). Undang-undang Republik Indonesia nomor 32 tahun 2002 tentang penyiaran. Jakarta: Penulis.

Rachmiatie, A., \& Suryadi, K. (2009). Sistem dan kebijakan komunikasi penyiaran di Indonesia. Bandung: Komisi Penyiaran Indonesia Daerah Jawa Barat. 
Steele, E. H. (2010). Examining the FCC's indecency regulations in light of today's technology. Federal Communications Law Journal, 63(289).

Syam, H. M., \& Nurrahmi, F. (2020). "I don't know if it is fake or real news" how little Indonesian university students understand social media literacy. Jurnal Komunikasi: Malaysian Journal of Communication, 36(2), 92-105. https://doi.org/10.17576/JKMJC-2020-3602-06 